(С) В.Н. Буркова, Ю.Н. Феденок

\title{
МЕДИЦИНСКАЯ МАСКА КАК СРЕДСТВО ИНДИВИДУАЛЬНОЙ И КОЛЛЕКТИВНОЙ ЗАЩИТЫ В УСЛОВИЯХ ПАНДЕМИИ COVID-19 (КРОСС-КУЛЬТУРНЫЕ АСПЕКТЫ)*
}

\author{
Носить маску - защищать себя - защищать других! \\ (выдержка из Руководства по ликвидации эпидемии: \\ советы для широких масс Китайская народная республика \\ (рассылается с 03.02.2020 г. смс-сообщениями каждому жителю Китая)
}

Использование медицинской маски - одна из профилактических мер по ограничению распространения респираторных инфекций, в том числе COVID-19. Частота использования маски в каждой стране зависит от многих факторов, среди них - эпидемиологический опьт, культурные нормы и установки, экономическая и политическая ситуаџия, степень информированности населения и др. Цель данного исследования - изучение первичной реакции населения разных стран, охваченных пандемией COVID-19, на предписания или рекомендации властей по использованию медицинских масок в качестве индивидуальной и коллективной защитыл. Мы применяли методы полуструктурированного глубинного интервью, анкетирование, фотофиксацию элементов поведения. Всего было собрано 366 анкет респондентов (51 муж. и 315 жен.) среди русскоязычных граждан, проживающих или пребываюших в других странах на момент вспьшки и распространения COVID-19, а также среди россиян из разных регионов России, за период с 23 марта по 10 апреля 2020 г. Анализ полученных данных показал, что частота использования масок зависит от таких параметров как страна нахождения респондента, пол, социильное дистанцирование и доверие к власти. Результаты исследования демонстрируют эффект транслируемых через государственные источники официальных решений на реальное поведение людей - при более серьезных мерах со стороны правительства, люди ответственнее относятся к вводимым мерам профилактики и лучше их исполняют. Интерпретаџия результа-

Буркова Валентина Николаевна - к.и.н., старший научный сотрудник, Институт этнологии и антропологии РАН (119991 Москва, Ленинский просп., 32а), преподаватель Международного центра антропологии, НИУ «Высшая школа экономики». Эл. почта: burkovav@gmail.com. Burkova, Valentina N. - PhD in Hist., Institute of Ethnology and Anthropology RAS, Lecturer in International Centre of Anthropology, National Research University Higher School of Economics (Moscow, Russia.). E-mail: burkovav@gmail.com. ORCID: https://orcid.org/0000-0003-4777-0224

Феденок Юлия Николаевна - к.и.н., научный сотрудник, Институт этнологии и антропологии РАН (119991 Москва, Ленинский просп., 32а). Эл. почта: fedenok.julia@gmail.com. Fedenok, Julia N. PhD in Hist., Institute of Ethnology and Anthropology RAS (Moscow, Russia). E-mail: fedenok.julia@, gmail.com. ORCID: https://orcid.org/0000-0001-6103-6064

* Исследование выполнено при финансовой поддержке РФФИ в рамках научного проекта № 20-04-60186 и в соответствии с планом научно-исследовательских работ Института этнологии и антропологии РАН 
тов рассмотрена с антропологической точки зрения согласно классификаuчи культур «Индивидуализм-Коллективизм». Данные результаты являются первым срезом исследования в период введения ограничений и отображают первую стадию реакции населения на принятые меры. Знание особенностей восприятия и исполнения населением санитарно-гигиенических предписаний может быть использовано при выборе наиболее оптимальных форм оповещения о санитарно-гигиенических рекомендаџиях и выработке действенных и эффективных методов побуждения к их исполнению населением.

Ключевые слова: медицинская маска, коронавирус, COVID-19, социокультурныле нормыл, индивидуализм, коллективизм; кросс-культурные различия

\section{Введение}

11 марта 2020 г. генеральный директор Всемирной организации здравоохранения (BO3) доктор Т.А. Гебрейесус заявил, что ситуацию с распространением коронавируса COVID-19 можно охарактеризовать как пандемию. ВО3 информировала, что данное вирусное заболевание передается от человека к человеку респираторно-капельным и контактным путем. Любой человек, находящийся в близком контакте (в пределах 1 м) с лицом, имеющим респираторные симптомы, такие как чихание и кашель, рискует подвергнуться воздействию потенциально инфекционных капель отделяемого из дыхательных путей больного (ВОЗ 2020).

Использование медицинской маски является одной из профилактических мер по ограничению распространения определенных видов респираторных инфекций, в том числе COVID-19 (SARS-CoV-2). Предыдущие эпидемии респираторных заболеваний (грипп, тяжелый острый респираторный синдром ТОРС и др.) показали, что использование масок, мытье рук и другие меры гигиены, закрытие школ и социальное дистанцирование, являются эффективными стратегиями раннего контроля до момента появления вакцин (Anderson, Heesterbeek et al. 2020; Lo, Tsang et al. 2005; MacIntyre, Cauchemez et al. 2009; Syed, Sopwith et al. 2003). Многие страны включили в свои планы борьбы с пандемией рекомендации по использованию масок для лица наряду с другими мерами ${ }^{1}$.

Государственная политика в периоды эпидемий чаще всего направлена на то, чтобы искусственно вызывать изменения в поведении людей, в частности стимулировать сокращение межличностных контактов и/или увеличение размера социальной дистанции, как часть поведенческой адаптации к эпидемиям (Феденок, Буркова 2020; Fenichel 2013). Принимаемые локальными правительствами ограничения имеют разные формы: от полностью контролируемого социального взаимодействия между людьми до небольших ограничений без четкого контроля властей. Результаты моделирования возможных вариантов распространения эпидемии COVID-19 показали, что реакция каждого человека на советы правительств стран мира по предот-

\footnotetext{
${ }^{1}$ Australian health management plan for pandemic influenza: important information for all Australians. Canberra: Department of Health and Ageing, Commonwealth of Australia; 2006. Department of Health and Human Services. HHS pandemic influenza plan. Washington: The Department 2005. National plan for the prevention and control of influenza pandemic. Paris: General Secretariat for National Defence 2007.
} 
вращению распространения заболевания не менее важная составляющая, чем предпринимаемые этими правительствами действия (Anderson, Heesterbeek et al. 2020). Поведение выздоровевших и/или невосприимчивых к болезни людей становится крайне важным для благосостояния и здоровья остальных групп населения.

Согласно изначальным предписаниям ВОЗ, рекомендовалось носить медицинские маски двум категориям людей - тем, кто уже болен или имеет симптомы респираторного заболевания, и тем, кто осуществляет уход за больными с коронавирусной инфекцией (Coronavirus 2020). Остальных людей носить маски ВО3 не обязывала, поскольку они не являются гарантированной защитой от заражения COVID-19, a снятие маски требует особой аккуратности - неосторожными движениями можно занести вирус на руки, кроме того бездумное ношение может создать у человека ложное ощущение безопасности. В июне 2020 г. ВОЗ обновила свои рекомендации, уточнив, что медицинские маски необходимо использовать, когда наблюдается ускоренное «активное массовое распространение» COVID-19 и нет возможности соблюдать дистанцию (ВОЗ пересмотрела 2020).

В настоящее время в кросс-культурной психологии существует множество исследований, указывающих на то, что культура влияет на физическое и психическое здоровье популяции, субъективное ощущение благополучия и счастья, продолжительность жизни (Лебедева, Чирков и др. 2007; Triandis 1994). Согласно позиции ВО3, психосоциальные факторы считаются ключевыми для сохранения здоровья и успешной социальной деятельности людей (Психическое здоровье 2020). В науке используется понятие «социальный капитал» как совокупность социальных связей вместе с набором ценностей, норм и моделей поведения, разделяемых членами группы и облегчающих кооперацию и взаимодействие как между членами группы, так и по отношению к группе как целому (Triandis 1994; Van Kemenade 2003). Многие исследователи подчеркивают роль этого капитала для сохранения здоровья людей (Росс, Нисбетm 1999; Almedom 2005). Однако, несмотря на социокультурные факторы, влияющие на отношение индивида к здоровью, в конечном итоге он сам принимает решение, каким моделям поведения в этой связи необходимо следовать (Лебедева, Чирков и др. 2007).

С социо-антропологической точки зрения использование масок или их игнорирование в условиях пандемии может служить показателем того, насколько культурные традиции и ценности влияют на применимость данной практики в той или иной популяции. В качестве одного из объяснений можно использовать теорию классификации культур «Индивидуализм-Коллективизм», предложенную Дж. Хофстедом и модифицированную другими исследователями (Hofstede 1981; House, Hanges et al. 2004). Традиционные подходы к объяснению связи между культурой и личностью утверждают, что такие культурные аспекты смягчают индивидуальную личность. Тем не менее, существует мнение о том, что совокупность личности формирует культурное измерение (Hofstede, McCrae 2004). Задолго до пандемии COVID-19 coциальные психологи отмечали, что для усиления предотвращения болезней и сохранения здоровья и благополучия необходимо, чтобы подход к проблеме здоровья был основан на понимании культуры, традиций, верований и моделей межличностного взаимодействия (Triandis 1994).

Цель данного исследования - изучение первичной реакции населения разных стран, охваченных пандемией COVID-19, коронавирусом тяжелого острого респи- 
раторного синдрома 2 (SARS-CoV-2), в особенности - России, на предписания или рекомендации властей использовать в качестве индивидуальной и коллективной защиты медицинские маски.

Задачи исследования - качественный и количественный анализ частоты использования медицинских масок в качестве средства индивидуальной и коллективной защиты в различных странах (в особенности в России), определение гендерных различий при использовании масок, исследование взаимосвязи использования медицинской маски с такими факторами, как страна происхождения, доверие к власти, возраст, образование, наличие несовершеннолетних детей, социальное дистанцирование, агрессивные и панические настроения, наличие стресса и ситуативная тревожность.

\section{Методы и участники исследования}

Данное исследование было проведено среди русскоязычных граждан, проживающих или пребывающих в других странах на момент вспышки и распространения COVID-19, а также россиян из разных регионов России. Мы использовали метод анкетирования, полуструктурированного глубинного интервью, метод «снежного кома» для организации опроса, фотофиксацию элементов поведения людей в условиях пандемии, анализ новостных сюжетов СМИ. Для опроса была использована специально созданная гугл-форма с открытыми, полуоткрытыми и закрытыми типами вопросов. Все использованные в статье фотографии публикуются с разрешения респондентов без указания личных данных.

Всего было собрано 366 анкет (51 мужчин и 316 женщин), возраст варьировал от 19 до 71 года (86\% респондентов - в возрасте от 25 до 48 лет). В нашу выборку попали русскоязычные граждане из 33 стран мира (табл. 1). На Россию приходится 65,5\% (239 чел.) выборки, остальные 34,5\% (127 чел.) - респонденты из других стран. Данные собраны за период с 23 марта по 10 апреля 2020 г. Исследование проводилось на добровольной и анонимной основе.

Таблица 1

Количество опрошенных респондентов по странам

\begin{tabular}{c|c|c}
\hline № & Страна & Количество опрошенных (чел.) \\
\hline 1. & Австрия & 1 \\
2. & Арабские Эмираты & 1 \\
3. & Армения & 3 \\
4. & Беларусь & 18 \\
\hline 5. & Болгария & 4 \\
\hline 6. & Великобритания & 4 \\
\hline 7. & Вьетнам & 1 \\
\hline 8. & Германия & 11 \\
\hline 9. & Греция & 2 \\
\hline
\end{tabular}


Таблица 1 (продолжение)

\begin{tabular}{|c|c|c|}
\hline № & Страна & Количество опрошенных (чел.) \\
\hline 10. & Грузия & 3 \\
\hline 11. & Дания & 2 \\
\hline 12. & Израиль & 6 \\
\hline 13. & Испания & 5 \\
\hline 14. & Италия & 2 \\
\hline 15. & Казахстан & 10 \\
\hline 16. & Кипр & 2 \\
\hline 17. & Киргизия & 2 \\
\hline 18. & Китай & 4 \\
\hline 19. & Латвия & 2 \\
\hline 20. & Малайзия & 1 \\
\hline 21. & Нидерланды & 2 \\
\hline 22. & Польша & 4 \\
\hline 23. & Россия & 239 \\
\hline 24. & Сингапур & 2 \\
\hline 25. & США & 3 \\
\hline 26. & Танзания & 3 \\
\hline 27. & Турция & 1 \\
\hline 28. & Узбекистан & 1 \\
\hline 29. & Украина & 16 \\
\hline 30. & Франция & 4 \\
\hline 31. & Чехия & 5 \\
\hline 32. & Швеция & 1 \\
\hline \multirow[t]{2}{*}{33.} & Эстония & 1 \\
\hline & ВСЕГО & 366 \\
\hline
\end{tabular}

Все анкеты были внесены в базу данных, при статистической обработке использован пакет программ SPPS-23. Для анализа применялись методы описательной статистики (частоты), сравнение групп по количественным признакам проводили с использованием критерия Стьюдента (Т-тест) для независимых выборок; оценка влияния независимых переменных на искомый признак (зависимую переменную использование масок) - методом линейной регрессии с оценкой достоверности и адекватности модели на основании однофакторного дисперсионного анализа по критерию Фишера $(\mathrm{F} \geq 4,7)$, коэффициенту детерминации $\left(\mathrm{R}^{2}\right)$ и $\mathrm{t}$-критерию Стьюдента 
$(\mathrm{t} \geq 2)$, оценку зависимостей между признаками - методом корреляционного анализа для количественных переменных с контролем. Уровнем статистической значимости являлась величина $\mathrm{p} \leq 0,05$.

\section{Результаты}

На основании пилотного исследования и персональных интервью вопрос «Носят ли в стране, где Вы в данный момент находитесь, медицинские маски?» был разбит на четыре наиболее употребляемые категории: не носят, носит 1-2 человека из толпы, носит каждый второй человек, носят все люди повсеместно. Был проведен линейный регрессионный анализ для общей выборки, чтобы понять, какие именно факторы влияют на использование маски в условиях пандемии коронавируса (табл. 2).

Таблица 2

Линейный регрессионный анализ со шкалой «использование маски» как зависимой переменной для общей выборки (N=366)

\begin{tabular}{|c|c|c|c|c|c|c|c|}
\hline 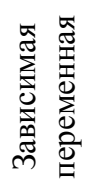 & $\begin{array}{l}\text { Независимые } \\
\text { переменные }\end{array}$ & $\approx$ & 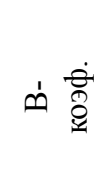 & 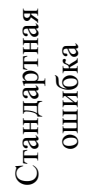 & 悹㻤 & 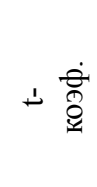 & $a$ \\
\hline \multirow{11}{*}{ 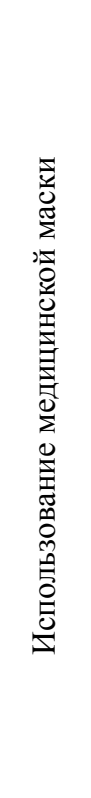 } & Страна & 0,013 & 0,011 & 0,005 & 0,114 & 2,184 & $\mathbf{0 , 0 3 0}$ \\
\hline & Пол & 0,032 & $-0,366$ & 0,106 & $-0,178$ & $-3,444$ & 0,001 \\
\hline & Возраст & 0,000 & 0,000 & 0,004 & $-0,003$ & $-0,055$ & NS \\
\hline & Образование & 0,000 & 0,005 & 0,047 & 0,005 & 0,097 & NS \\
\hline & $\begin{array}{l}\text { Наличие } \\
\text { несовершеннолетних детей }\end{array}$ & 0,004 & 0,091 & 0,080 & 0,060 & 1,138 & NS \\
\hline & $\begin{array}{l}\text { Социальное } \\
\text { дистанцирование }\end{array}$ & 0,071 & 0,305 & 0,094 & 0,226 & 3,260 & 0,001 \\
\hline & Агрессивные настроения & 0,001 & $-0,043$ & 0,102 & $-0,023$ & $-0,426$ & NS \\
\hline & Панические настроения & 0,008 & 0,121 & 0,093 & 0,087 & 1,298 & NS \\
\hline & Доверие к власти & 0,069 & 0,363 & 0,096 & 0,262 & 3,802 & 0,000 \\
\hline & Наличие стресса & 0,001 & $-0,015$ & 0,031 & $-0,024$ & $-0,463$ & NS \\
\hline & Ситуативная тревожность & 0,009 & $-0,006$ & 0,003 & $-0,095$ & $-1,821$ & 0,069 \\
\hline
\end{tabular}

* Условные обозначения: $\mathrm{R}^{2}$ - коэффициент детерминации (объясняет процент изменчивости по каждому из тестируемых признаков); P - значимость; NS - не значимо.

Линейная регрессия для целой выборки показала значимый положительный эффект страны нахождения респондента и значимый отрицательный эффект пола респондента на использование масок (табл. 2). Кроме того, значимыми предикторами использования масок в условиях пандемии были социальное дистанцирование (зна- 
ние людей о наличии конкретного указания властей государства на необходимую дистанцию общения между людьми) и доверие к власти (наличие или отсутствие). Остальные показатели не показали значимых эффектов (табл. 2).

Поскольку данные по другим странам слишком малы, чтобы проводить отдельный количественный анализ по каждой стране, мы представляем частоту использования масок только по России (рис. 1). Эти данные отражают ответы людей на момент введения и первых двух недель режима самоизоляции и ограничительных мер. Большая часть опрошенных $(61,1 \%)$ указала, что используют маски 1-2 человека из толпы, 26,8\% респондентов отметили, что маски носит каждый второй человек из толпы, ответы «не носят маски совсем» и «носят повсеместно» отметили, соответственно, $5,9 \%$ и $6,3 \%$ участников опроса (рис. 1 ).

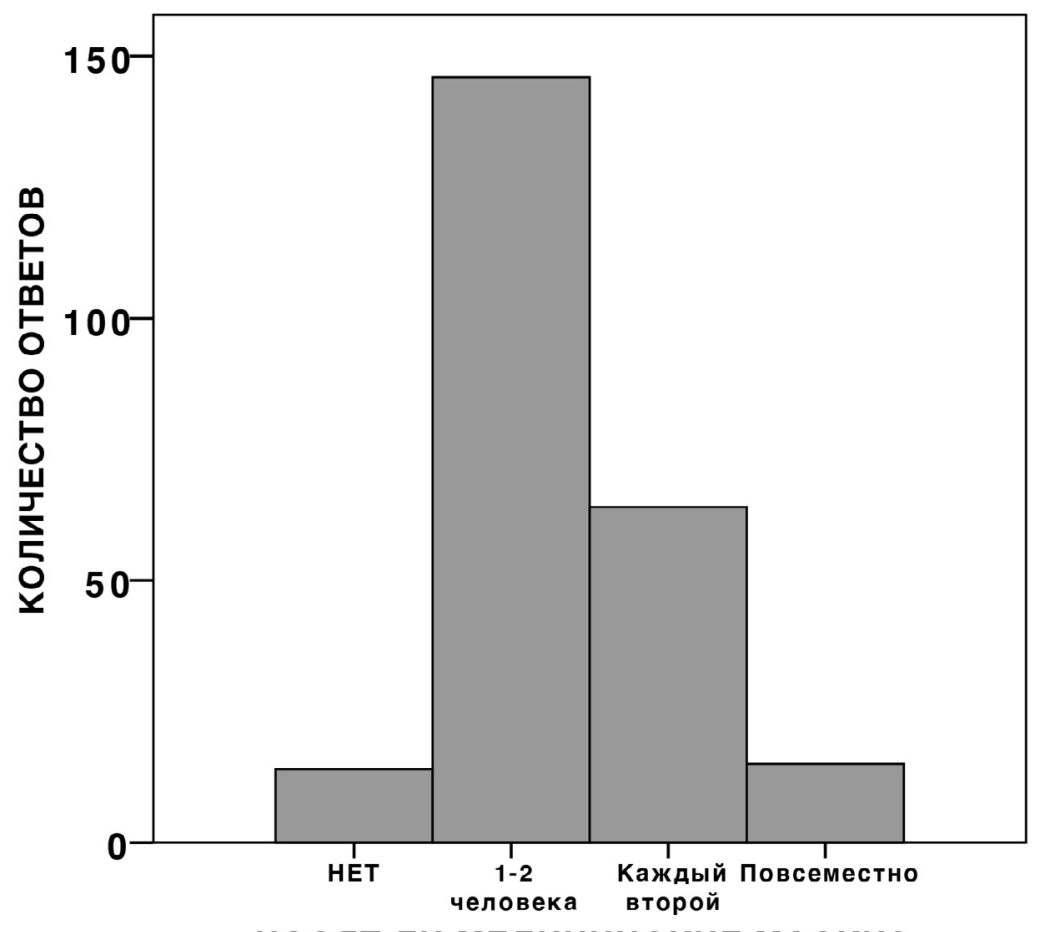

НОСЯТ ЛИ МЕДИЦИНСКИЕ МАСКИ?

Рис. 1. Частота использования масок как средства защиты от коронавируса в России

Поскольку линейный регрессионный анализ показал значимый эффект фактора пола на использование масок, нами был проведен Т-тест для независимых выборок, который подтвердил наличие значимых гендерных различий по данному признаку $(\mathrm{t}=3,444 ; \mathrm{df}=362 ; \mathrm{p}=0,001)$. С использованием методов описательной статистики (частоты) были получены следующие результаты (рис. 2): мужчины из всех стран отмечали примерно поровну, что маски в общественных местах носят 1-2 человека из толпы $(41,67 \%)$ или каждый второй $(47,92 \%)$, тогда как гораздо больше женщин указали на то, что носят маски 1-2 человека (61,8\%), чем каждый второй (24,84\%) (рис. 2). Женщины также указали гораздо больше случаев, когда маски не носят совсем (7,76\%) по сравнению с мужчинами (2,08\%). На наш взгляд эти различия связаны с гендерными особенностями восприятия людей в целом и восприятия лиц людей, 
в частности. Известно, что женщины лучше распознают чужие эмоции и более эмпатичны, такие гендерные различия прослеживаются на кросс-культурном уровне (Буркова, Бутовская и др. 2019; Буркова, Феденок и др. 2019; Baron-Cohen, Wheelwright 2004; Zahn-Waxler, Robinson et al. 1992). Вероятно, опрошенные женщины более внимательно рассматривали окружающих их людей и дали более реальную картину ношения медицинских масок среди населения разных стран.
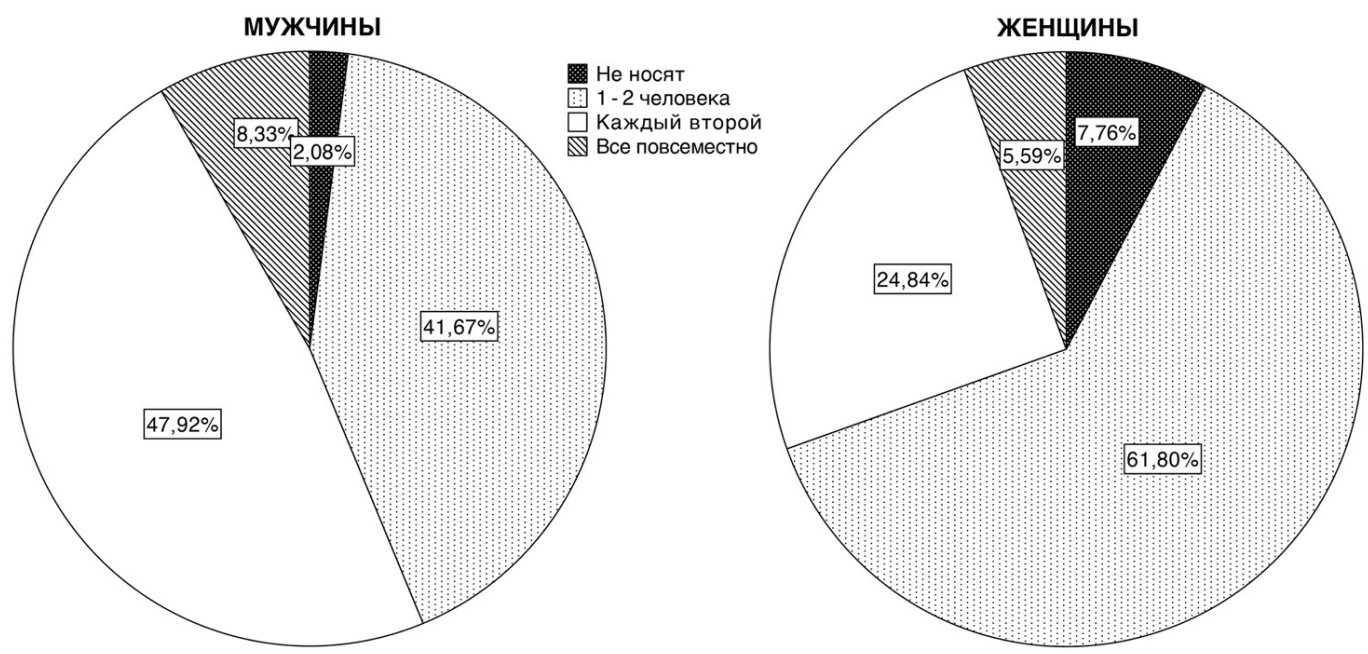

Рис. 2. Ответы мужчин и женщин об использовании масок в общественных местах (общая выборка).

Далее мы проверили взаимосвязь между использованием медицинских масок и социальной дистанцией, применив корреляционный анализ с контролем по стране пребывания респондента - была обнаружена значимая положительная связь между данными параметрами $(\mathrm{r}=0,260, \mathrm{df}=139, \mathrm{p}=0,002)$. Под социальной дистанцией мы подразумевали четкое указание властей государства на необходимое расстояние общения между людьми, то есть респондент, ссылаясь на какие-либо официальные источники, назвал конкретную дистанцию в метрах, на которой дано предписание общаться между людьми (Феденок, Буркова 2020). Данный результат показывает, что по мере увеличения дистанции общения (от 1 до 3 м), о которой информирован человек, увеличивается и частота использования масок (ответы от «не используют» до «используют повсеместно»). По-видимому, оценка ситуации респондентами через призму информированности о социальной дистанции, указавшими бо́льшую дистанцию и при этом бо́льшую частоту ношения масок, может отражать более серьезное отношение властей к принимаемым на государственном уровне ограничительным мерам и бо́льшие затраты на информирование о принимаемых мерах и профилактике. Как следствие, бо́льшую осторожность проявляет и население - они носят медицинские маски чаще. По-видимому, мы видим эффект транслируемых через государственные источники официальных решений на реальное поведение людей - при более серьезных мерах со стороны правительства люди ответственнее относятся к вводимым мерам профилактики и лучше их исполняют.

Принимая во внимание данный результат, не вызывает удивления и наличие взаимосвязи между использованием масок и доверием к власти. Мы задали респон- 
дентам вопрос о доверии местных жителей той информации, которая исходит из официальных источников (федеральный каналы, заявления правительства и нормативно-правовые акты). Корреляционный анализ с контролем по стране пребывания респондента показал наличие значимой положительной связи между использованием маски (от «не носят» до «носят повсеместно») в условиях пандемии и доверием к власти (от «не доверяю» к «доверяю») $(\mathrm{r}=0,260, \mathrm{df}=195, \mathrm{p}=0,000)$.

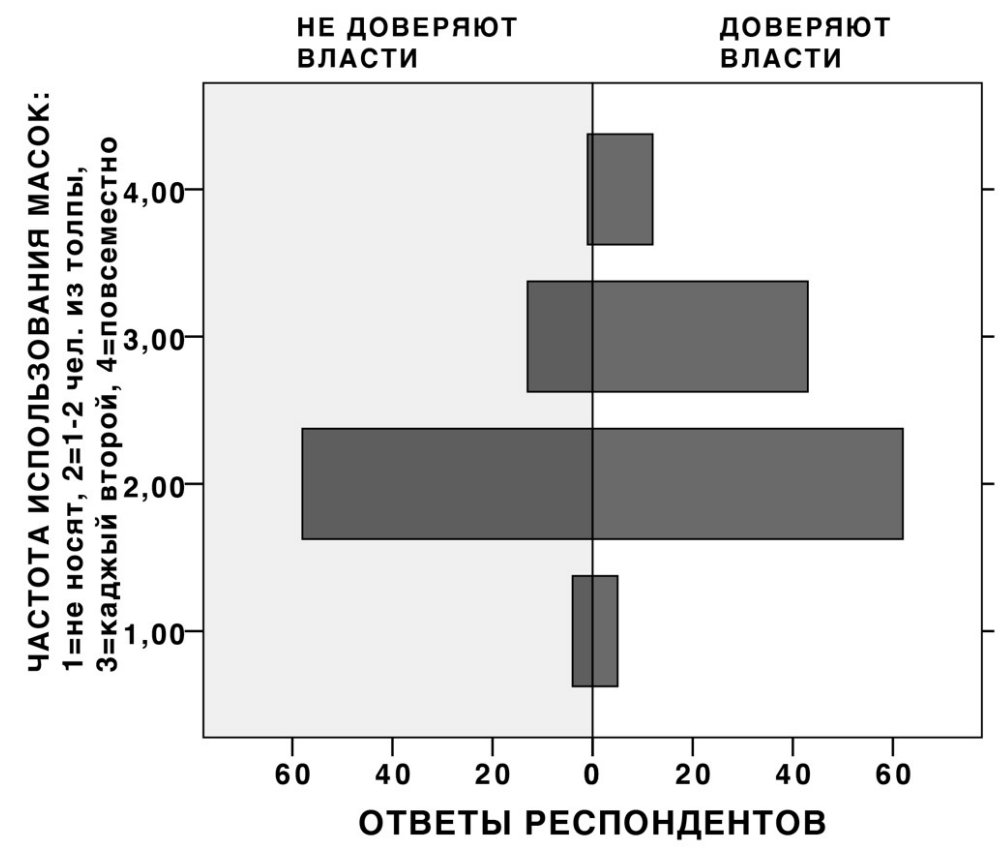

Рис. 3. Ответы респондентов об использовании масок в общественных местахв зависимости от доверия к власти (общая выборка)

На рис. 3 показано, как распределились ответы респондентов: в сером левом столбце приведены ответы тех, кто не доверяет власти, с градацией ответов от «не носят» до «носят повсеместно». Правый белый столбец демонстрирует ответы тех людей, которые отметили, что доверяют власти. Все из представленных нами стран давали в официальной информации рекомендации по профилактике коронавируса, в частности, о необходимости использования медицинских масок в общественных местах. Особого внимания заслуживают ответы тех, кто указал категорию «носит каждый второй» и «повсеместно» - их гораздо больше среди тех респондентов, которые доверяют решениям правительств стран, где находятся, и стараются их исполнять. Регрессионный анализ отдельно по российской выборке также показал значимый положительный эффект показателя «доверие к власти» на вопрос об использовании масок $(\mathrm{B}=0,335$; $\left.\mathrm{SE}=0,101 ; \mathrm{t}=3,332 ; \mathrm{p}=0,001 ; \mathrm{R}^{2}=0,062\right)$. Профиль ответов соответствует рис. 3 по общей выборке, поэтому мы не приводим отдельный рисунок.

C начала вспышки COVID-19 жители некоторых стран начали носить маски как должное, в том числе боясь общественного осуждения, например, в Китае (в том числе Гонконге), Таиланде, Японии, Тайвани, Южной Корее. В других странах - России, Великобритании, США, многих европейских странах, Австралии - осталось вполне приемлемым ходить с открытым лицом, несмотря на увеличивающиеся с каждым днем 
цифры зараженных людей. Отдельно мы хотим остановиться на отношении к использованию масок в различных странах, исходя из глубинных интервью с респондентами, поскольку имеющихся данных по каждой отдельной стране на текущем этапе недостаточно для проведения статистического анализа. Каждый регион выработал в период ухудшения эпидемиологической обстановки свое отношение к использованию медицинских масок как средства индивидуальной и коллективной защиты от заражения COVID-19. Так, например, в Италии, одном из регионов с самой тяжелой эпидемиологической ситуацией - Ломбардии, был установлен абсолютный запрет входа без маски в общественные места (Рис. 4).

В Китае с распространением вируса было введено тотальное ношение масок: «Китайцы очень послушные. Если пришло распоряжение сверху надеть маски, то на следующий день 99\% людей вышли в масках. Нет вопроса хочу - не хочу. Я единственная вышла без маски в первый день эпиде-

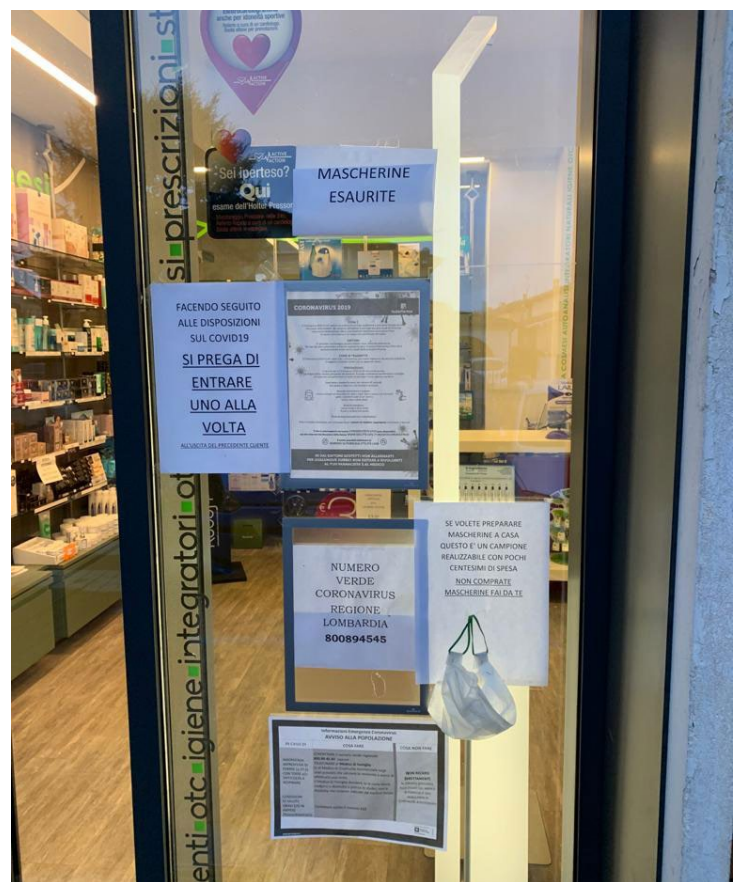

Рис. 4. Дверь аптеки в Ломбардии (Италия)

с указаниями о запрете входа без маски, объявлением об отсутствии масок в продаже и инструкцией о том, как сделать маску из салфеток с образиом (фото респондента, мужчина, 52 года, Италия, 23.03.20202.)

мии. Сосед на лестничной клетке меня увидел и вынес мне 2 респиратора, подарил. Эффект от масок будет только в том случае, если все поголовно будут в масках» (женщина, 38 лет, г. Пекин, КНР).

Помимо беспрекословного выполнения китайцами указов правительства и возможные санкции со стороны государственной власти, важными факторами применимости практики ношения маски являются личные установки граждан, выработанные благодаря имеющемуся опыту. Вспышка вируса SARS в юго-восточной Азии в 2002-03 гг. показала важность данного вида профилактики при респираторных эпидемиях. Местные жители выработали привычку носить медицинские маски не только в случае эпидемии, но и во время своей болезни для того, чтобы не заражать других членов общества (Рис. 5). Данные установки были отмечены нашими респондентами из Сингапура, Китая, Вьетнама. Местные жители исполняют на 90-100\% рекомендации правительства, даже если они не даны в виде нормативных актов. «Основное, что заставляет людей выполнять рекомендации - самосознание общества, и лишь немного полиция...» (женщина, 39 лет, г. Хошимин, Вьетнам, 25.03.2020 г.). Интересно, что респонденты отмечают культурные привычки местных жителей, которые могут влиять на распространение вируса: «В данном случае маски просто необходимы китайцам, потому что они в принципе не прикрываются, когда чихают или кашляют, или рыгают» (женщина, 38 лет, г. Пекин, КНР). 


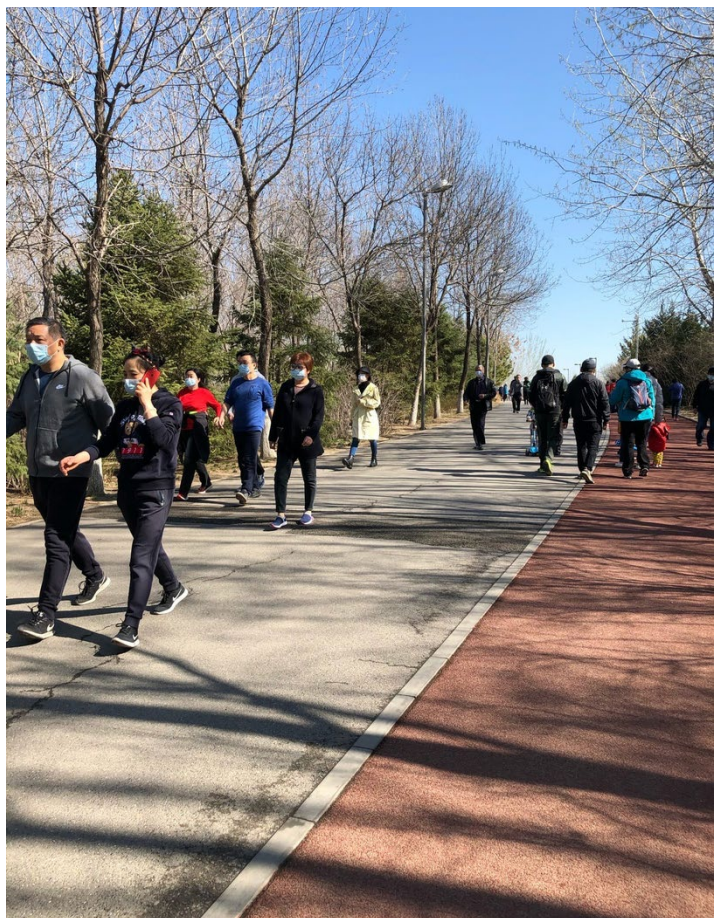

Рис. 5. Повсеместное использование масок в КНР (фото респондентки, 38 лет, г. Пекин, КНР, 20.03.2020г.).

В европейских странах ношение маски изначально не является принятой нормой поведения в периоды респираторных заболеваний, и те, кто ходит в маске, часто сталкиваются с насмешками, недоверием и даже агрессией со стороны окружающих. Нами был проинтервьюирован 51 респондент, находящийся в странах Европы на момент проведения опроса. Большинство опрошенных (69,23\%) отметили, что маски носят 1-2 человека из толпы, 15,38\% - каждый второй на улице, 9,62\% - вообще не носят, а $5,77 \%$ - носят повсеместно. Однако, в каждой из стран Европы сложилась своя уникальная ситуация, зависимая от многих факторов, среди которых количество заболевших, информированность населения государственными структурами, доверие к власти, доступность средств защиты, этнокультурные особенности людей и особенности социо-культурных норм поведения в каждой из стран.

С нарастанием количества заболевших во многих странах восприятие масок поменялось, особенно в Италии и Испании. Все респонденты отмечают тот факт, что к ношению масок «сначала все относились легкомысленно, но потом резко все изменилось» (мужчина, 52 года, Ломбардия, Италия, 25.03.2020г.). «Изначально легкомысленное отношение было - у нас $30 \%$ студентов - китайцы, которые на каждые каникулы ездят к себе в Китай. Им просто рекомендовали после приезда посидеть две недели дома. Никто не занимался никаким контролем. Мы две недели подряд с интервалом в пару дней получали письма от университета - не паникуйте, все нормально, мы следим за обстановкой. Все хорошо! А в понедельник приходит уже письмо в стиле паники: универ закрыт, мы переходим на дистанционное обучение! И резко все поменялась ситуация - за одну ночь! Вдруг на ТВ уже обсуждают как ввести военное положение (даже не ЧС) и полностью изолировать остров» (мужчина, 21 год, Лондон, Англия (14.03.2020г.). С распространением COVID-19 по всей Италии был введен категорический запрет на вход в продуктовые магазины и аптеки без масок. За неимением масок в продаже, люди стали использовать самодельные маски и даже строительные респираторы (Рис. 6). В Германии информанты сообщили, что маски у них не носят или носят только больные люди, однако это связано с введением комендантского часа и отсутствием самого факта перемещения без уважительной причины (женщина, 44 года, г. Берлин, Германия, 24.03.2020г). В Испании, напротив, указывают на повсеместное использование масок: «когда мы ходили в магазин, мы видели людей, едущих в своих закрытых машинах в масках, мы видели таксистов 
в масках без клиентов в машине» (женщина, 39 лет, Испания, 28.03.2020г.).

В Болгарии отмечают, что «местные очень осторожные и боязливые, власти довольно рано стали вводить ограничительные мероприятия... Как результат местное население практически повсеместно носит маски и перчатки, соблюдает дистанцию, минимизирует контакты. В итоге мы видим, что количество заболевших не растет с такой скоростью как, например, в Италии или Испании. Люди это видят и,

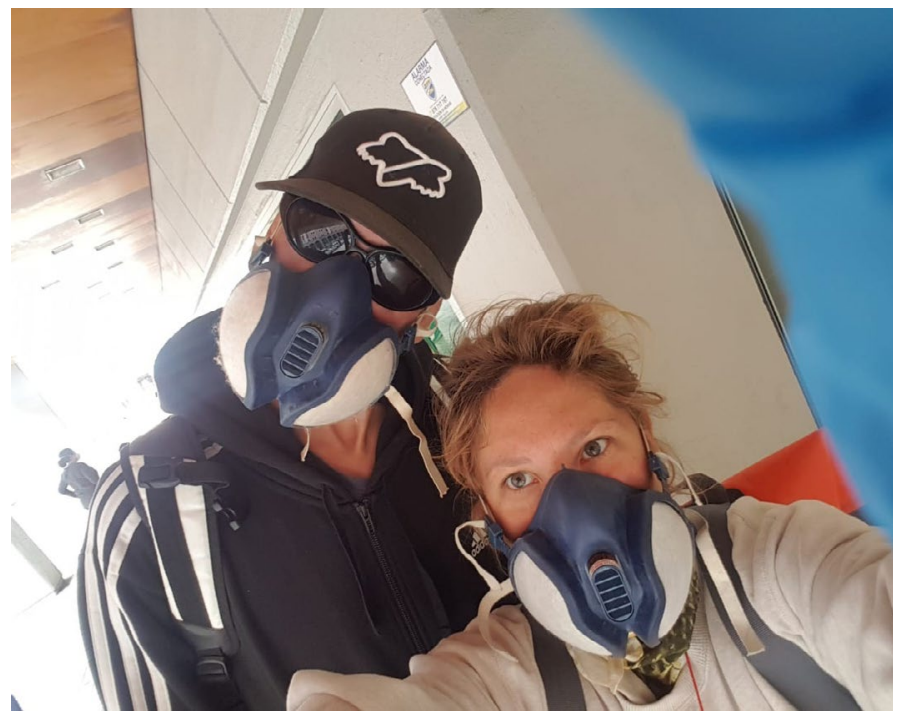

Рис. 6. Использование строительных респираторов в разгар эпидемии в Испании (фото респондентов, 39 лет, 25.03.2020г.) в целом, доверяют своему правительству» (женщина, 38 лет, г. София, Болгария). Однако, стоит заметить, что реальность использования масок зависит и от их наличия в прямом доступе. Маски носят «все повсеместно, но масок нет в продаже, и многие носят маски повторно, не соблюдая правила использования» (женщина, 42 года, г. Банско, Болгария). «Масок нет в продаже. Даже при желании носить - это невозможно, нет в аптеках» (женщина, 38 лет, г. Хайдерберг, Германия).

В России строгого предписания правительства носить маски не было до середины мая. В общественном транспорте, включая пригородные электрички и метро, на улицах, в поликлиниках, магазинах, по нашим наблюдениям в конце марта и в апреле 2020 г. в масках ходило около 15-30\% населения (Рис. 7). При этом окружающие воспринимали людей в масках как что-то чуждое и странное, приписывая им высокую степень чудачества. В начале развития эпидемии зачастую и медицинские работники принимали пациентов без масок или надевали маски только на рот. По мере роста числа инфицированных и ужесточения эпидемиологических мер, все большее число людей стало носить маски как в столице, так и в регионах. К середине апреля в Московском регионе медицинские маски стали носить около 60\% жителей. Исключением являлись подростки, а также пожилые люди в общественных местах с симптомами респираторных заболеваний и без медицинских масок. Носят «большинство, но некоторые не надевают их на нос. Снимают маски, когда говорят по телефону, не уверена, что все знают, что телефон нужно дезинфицировать» (женщина 28 лет, г. Раменское, МО, Россия).

В Танзании в начале эпидемии отмечалось, что «люди стали носить медицинские маски, но при встрече со знакомым снимали их, так как неудобно (невежливо) разговаривать в маске» (женщина 33 года, г. Дар-эс-Салам, Танзания). Имеется в виду не только физическое неудобство, но и принятые нормы общения, что в свою очередь указывает на необходимость учета культурных особенностей при рекомендациях населению и проведению санпросвещения в каждом конкретном регионе. 


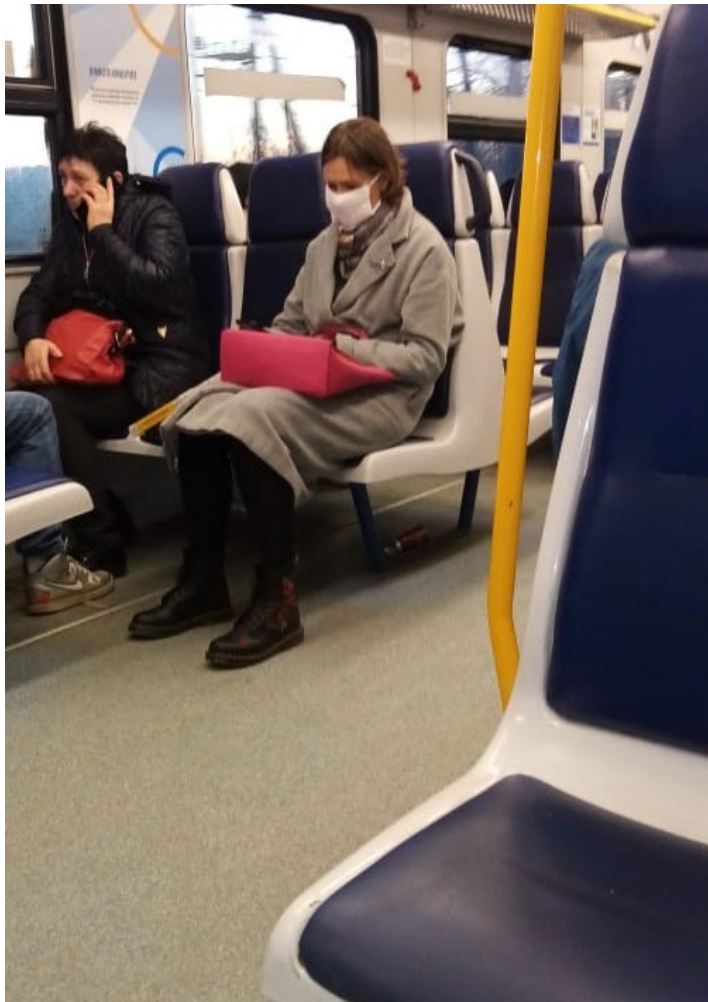

Рис. 7. Ношение масок в пригородной электричке направления г. Москва - 2. Лобня в начале эпидемии в России (фото респондентки, 41 г., г. Лобня 05.04.2020г.)

\section{Обсуждение}

Полученные нами данные показали, что значимыми предикторами использования медицинских масок населением в условиях пандемии COVID-19 является страна проживания, социальное дистанцирование (наличие конкретного указания властей государства на необходимую дистанцию общения между людьми) и доверие к власти (наличие или отсутствие).

Опыт Китая показывает, что карантин, социальное дистанцирование и меры профилактики, в том числе повсеместное использование медицинских масок как определенный акт альтруизма по отношению к своим соотечественникам, помогают сдерживать распространение эпидемии. Из данных ежедневно обновляемой официальной статистики, очевидно, что жесткие меры в азиатских странах приводят к хорошим результатам, в то время как в странах Европы вирусом заражается все больше людей (Worldometers 2020). Приверженность профилактическим мерам варьирует в зависимости от восприятия риска (Cava, Fay et al. 2005) и возрастает во время эпидемий (MacIntyre, Cauchemez et al. 2009). Важным фактором применимости практики ношения маски является наличие эпидемиологического опыта. Сингапур и Гонконг в 2002-2003 г. перенесли тяжелые эпидемии острого респираторного синдрома (ТОРС) и смогли справиться с распространением болезни благодаря ранним действиям правительства и мерам социального дистанцирования, принятыми отдельными лицами (Anderson, Heesterbeek et al. 2020). Местные жители выработали привычку носить медицинские маски не только в случае эпидемии, но и при любой респираторной болезни для того, чтобы не заражать других членов общества. В разгар эпидемии атипичной пневмонии в апреле и мае 2003 г. в Гонконге соблюдение мер инфекционного контроля было высоким: 76\% населения носили лицевую маску, 65\% мыли руки после соответствующего контакта и 78\% прикрывали рот при чихании или кашле ( $L o$, Tsang et al. 2005). Предыдущие исследования показывали, что культурный контекст сильно влияет на приверженность мерам профилактики - азиатские культуры более склонны использовать маски (Syed, Sopwith et al. 2003). Потенциальная эффективность масок увеличивается в тех случаях, когда можно ожидать большей приверженности этой «традиции», например, во время тяжелой пандемии гриппа или других вирусов (MacIntyre, Cauchemez et al. 2009). Не стоит забывать и о том факте, что наличие маски на лице уменьшает передачу вируса или инфекции, поскольку минимизирует тактильные самоконтакты индивида (уменьшается количество прикосновений к рту, 
носу, лицу) (ibid.). Эти результаты согласуются и с нашими данными, полученными от информантов из стран Азии - Сингапура, Китая, Кореи, Вьетнама. В Южной Корее важной составляющей борьбы с COVID-19 стал высокий уровень гражданской ответственности и коллективизма. Корейцы очень исполнительны в отношении требований и рекомендаций национального министерства здравоохранения в период эпидемии: все соблюдают правила гигиены, носят маски, и в целом более ответственны к своему здоровью. Кроме того, правительство последовательно придерживается принципа прозрачности в части информирования населения об эпидемии, повышая тем самым взаимное доверие между властью и обществом (Ким 2020). Согласно результаты нашего исследования, как по российской выборке, так и по общей выборке, наличие доверия к правительству во всех странах, а, следовательно, и информации, получаемой из официальных источников, является важным фактором для успешной борьбы с эпидемиями. Такую же тенденцию мы наблюдали при анализе взаимосвязи вопроса о доверии к власти и социальной дистанции: при наличии доверия к власти люди демонстрируют лучшую осведомленность о предписанной дистанции общения в ситуации пандемии COVID-19 и указывают на более длинную дистанцию общения (Феденок, Буркова 2020).

Согласно классификации культур «Индивидуализм-Коллективизм» в исследовании, проведенном ранее в 78 странах, на западе (прежде всего, Европа и США) преобладает индивидуализм, в то время азиатские страны относятся к коллективистским. Япония в этом измерении занимает средние позиции (Hofstede, Hofstede et al. 2010). В индивидуалистических культурах связи между индивидами нежесткие: каждый отвечает сам за себя и свою нуклеарную семью, тогда как в коллективистских культурах люди с рождения интегрированы в сильные, прочные группы, которые оберегают их, взамен получая беспрекословную преданность, и противостоят другим группам (Хофстеде 2014). Данная классификация может служить одним из объяснений как степени распространения COVID-19, так и успешности борьбы с ним. На сегодняшний день, в коллективистских странах наблюдаются более успешные тенденции в борьбе с пандемией.

Личные действия или бездействия в западных демократиях могут быть более важной проблемой, чем действия их правительств (Anderson, Heesterbeek et al. 2010). В странах Европы и США имеются очевидные проблемы в этом направлении. Жители Франции долгое время посещали общественные места без перчаток или масок, подвергая себя и окружающих повышенной опасности и увеличивая риск заражения инфекцией (Фабергас 2020). Многие респонденты из Италии, Англии, Испании отмечали легкомысленное отношение местных жителей к пандемии, причем связано это было не только с действиями правительства, но и с менталитетом жителей. Хотя научные исследования, проведенные в этих странах, показывают, что у приверженцев использования масок значительно снижается риск развития клинических инфекций (MacIntyre, Cauchemez 2020).

Согласно имеющимся исследованиям, Россия представляет собой синкретизм ценностей коллективизма, а также русского и западного типов индивидуализма (Войтенко, Соколов и др. 2019). Она входит в число стран с одним из самых высоких показателей в рейтинге «дистанцированность власти» (степень, с которой облечённые меньшей властью члены организаций и институционализированных групп принимают неравное распределение власти и ожидают этого неравенства) (Хофстеде 
2014; Javidan, Dastmalchian 2009). Важность этого фактора, применительно к сфере здравоохранения, показывает ряд других исследований. Анализ кросс-культурных различий показал, что такие культурные измерения как высокая дистанция власти и ценности иерархии (вертикальное устройство общества и моделей взаимодействия) оказывают негативное воздействие на отношение россиян к своему здоровью (Лебедева, Чирков и др. 2007). Согласно результатам зарубежных исследований, россияне отличаются более низкой самодетерминацией поведения в целом и в отношении сохранения здоровья, в частности (Chirkov, Ryan et al. 2003). Эти факторы могут оказывать негативное влияние на распространение пандемии в России.

\section{Заключение}

Знание социокультурных и этнических особенностей восприятия и исполнения населением разных стран санитарно-гигиенических предписаний может иметь прикладное значение и способствовать выбору наиболее оптимальных форм оповещения людей о необходимых мерах профилактики, а также использоваться при выработке действенных и эффективных методов побуждения к их исполнению среди широких масс. При оповещениях населения необходимо учитывать культурные установки на индивидуализм или коллективизм, а также индекс доверия власти у населения разных стран. Формами оповещения населения могут быть как повелительные, так и рекомендательные предписания, а средствами информирования могут выступать смс-рассылка, телевизионные ролики, радиосообщения, интернет-публикации, трансляция посредством уличных рупорных громкоговорителей, объявления в магазинах и аптеках и др.

\section{Источники}

BО3 2020 - ВО3 объявила о начале пандемии COVID-19 (http://www.euro.who.int/ru/healthtopics/health-emergencies/coronavirus-covid-19/news/news/2020/3/who-announces-covid-19outbreak-a-pandemic) (23.03.2020)

Воз пересмотрела 2020 - ВОЗ пересмотрела взгляды на маски и советует носить их всем (https://www.interfax.ru/world/712063) (10.06.2020)

Психическое здоровье 2020 - Психическое здоровье. Основные факторы. ВО3. (https://www. medlit.ru/journalsview/gigsan/author_rules/) (16.04.2020)

Coronavirus 2020 - Coronavirus disease (COVID-19) advice for the public: When and how to use masks (https://www.who.int/emergencies/diseases/novel-coronavirus-2019/advice-for-public/ when-and-how-to-use-masks) (03.04.2020)

Worldometers 2020 - https://www.worldometers.info/coronavirus/ (20.04.2020)

\section{Научная литература}

Буркова В.Н., Феденок Ю.Н., Бутовская М.Л. Эмпатия и интолерантность российской молодежи в отношении инвалидов: половые и личностные различия // Экспериментальная психология. 2019. Том 12. № 1. С. 53-69.

Буркова В.Н., Бутовская М.Л., Дронова Д.А., Апалькова Ю.И. Эмпатия, тревожность и агрессия у московских студентов // Этнографическое обозрение. 2019. № 5. С. 169-188.

Войтенко В.П., Соколов В.А., Лубский Р.А. Коллективизм и индивидуализм в России как предмет теоретической рефлексии // Философия права. 2019. Т. 3. № 90. С. 71-77.

Ким Н. Уличные тесты и СМС-рассылки: как Южная Корея взяла под контроль эпидемию коронавируса // Forbes. https://www.forbes.ru/tehnologii/395939-ulichnye-testy-i-sms-rassylkikak-yuzhnaya-koreya-vzyala-pod-kontrol-epidemiyu (дата обращения 25.03.2020). 
Лебедева Н.М., Чирков В.И., Татарко А.Н. Культура и отношение к здоровью: Россия, Канада, Китай. М.: Изд-во РУДН, 2007. 314 с.

Росс Л., Нисбетт Р. Человек и ситуация. Уроки социальной психологии. М.: Аспект Пресс, 1999.

Феденок Ю.Н., Буркова В.Н. Социальное дистанцирование как альтруизм в условиях пандемии коронавируса: кросс-культурное исследование // Сибирские исторические исследования. 2020. № 2. С. 6-40.

Хофстеде $Г$. Модель Хофстеде в контексте: параметры количественной характеристики культур // Язык, коммуникация и социальная среда. 2014. № 12. С. 9-49.

Almedom A.M. Social capital and mental health: An interdisciplinary review of primary evidence // Social science \& Medicine. 2005. Vol. 61. P. 943-964. DOI: 10.1016/j.socscimed.2004.12.025

Anderson R.M., Heesterbeek H., Klinkenberg D., Hollingsworth T.D. How will country-based mitigation measures influence the course of the COVID-19 epidemic? // The Lancet. 2020. Vol. 395. No. 10228. P. 931-934. DOI: 10.1016/S0140-6736(20)30567-5

Baron-Cohen S., Wheelwright S. The Empathy Quotient: An Investigation of Adults with Asperger Syndrome or High Functioning Autism, and Normal Sex Differences // Journal of Autism and Developmental Disorders. 2004. Vol. 34. No. 2. P. 163-175. DOI: 10.1023/B:JA DD.0000022607.19833.00

Cava M.A., Fay K.E., Beanlands H.J., McCay E.A., Wignall R. Risk perception and compliance with quarantine during the SARS outbreak. // J Nurs Scholarsh. 2005. Vol. 37. P. 343-347. DOI: $10.1111 / \mathrm{j} .1547-5069.2005 .00059 . x$

Chirkov V.I., Ryan R.M., Kim Y., Kaplan U. Differentiating autonomy from individualism and independence: A self-determination theory perspective on internalization of cultural orientations and well-being // Journal of Personality and Social Psychology. 2003. Vol. 8. No. 1. P. 97-110.

Fenichel E.P. Economic considerations for social distancing and behavioral based policies during an epidemic // Journal of Health Economics. 2013. Vol. 32. P. 440-451. DOI: 10.1016/j. jhealeco.2013.01.002

Hofstede G. Culture and organizations // International Studies of Management and Organizations. 1981. Vol. 10. P. 15-41.

Hofstede G., Hofstede G.J., Minkov M. Cultures and Organizations: Software of the Mind. Revised and expanded third edition. New-York: McGraw-Hill, 2010.

Hofstede G., McCrae R. Personality and culture revisited: Linking traits and dimensions of culture // Cross-Cultural Research. 2004. Vol. 38. No. 1. P. 52-88.

House R.J., Hanges P.J., Javidan M., Dorfman P.W., Gupta V. (Eds.). Culture, leadership, and organizations: The GLOBE study of 62 societies. Sage publications. 2004. 848 p.

Javidan M., Dastmalchian A. Managerial implications of the GLOBE project: A study of 62 societies // Asia Pacific Journal of Human Resources. 2009. Vol. 47. No. 1. P. 41-58.

Lo J.Y.C., Tsang T.H.F., Leung Y.-H., Yeung E.Y.H., Wu T., Lim W.W.L. Respiratory infections during SARS outbreak, Hong Kong, 2003 // Emerg Infect Dis. 2005. Vol. 11. P. 1738-41. DOI: 10.3201/eid1111.050729.

MacIntyre C., Cauchemez S., Dwyer D.E., Seale H., Cheung P., Browne G., et al. Face Mask Use and Control of Respiratory Virus Transmission in Households // Emerg Infect Dis. 2009. Vol. 15. P. 233-241. DOI: 10.3201/eid1502.081167.

Syed Q., Sopwith W., Regan M., Bellis M.A. Behind the mask. Journey through an epidemic: some observations of contrasting public health responses to SARS // J Epi Comm Health. 2003. Vol. 57. P. 855-856.

Triandis H C. Culture and Social Behavior. New York: McGraw-Hill. 1994.

Van Kemenade S. Social capital as a health determinant: how is it defined? Ottawa: Minister of Public Works and Government Services Canada, 2003. Working Paper 02-07. http://publications.gc.ca/ collections/Collection/H13-5-02-7E.pdf

Zahn-Waxler C., Robinson J.L., Emde R.N. The Development of Empathy in Twins // Developmental Psychology, 1992. Vol. 28. No. 6. P. 1038-1047. DOI: 10.1037/0012-1649.28.6.1038 


\section{References}

Almedom, A.M. 2005. Social capital and mental health: An interdisciplinary review of primary evidence. Social science \& Medicin 61: 943-964. DOI: 10.1016/j.socscimed.2004.12.025

Anderson, R.M., H. Heesterbeek, D. Klinkenberg, and T.D. Hollingsworth. 2020. How will country-based mitigation measures influence the course of the COVID-19 epidemic? The Lancet 395(10228): 931-934. DOI: 10.1016/S0140-6736(20)30567-5

Baron-Cohen, S., and S. Wheelwright. 2004. The Empathy Quotient: An Investigation of Adults with Asperger Syndrome or High Functioning Autism, and Normal Sex Differences. Journal of Autism and Developmental Disorders 34(2): 163-175. DOI: 10.1023/B:JADD.0000022607.19833.00

Burkova, V.N., J.N. Fedenok, and M.L. Butovskaya. 2019. Empatija i intolerantnost' rossijskoj molodezhi v otnoshenii invalidov: polovye i lichnostnye razlichija [Empathy and intolerance of Russian youth towards people with disabilities: gender and personality differences]. Eksperimental'naya psikhologiya 12(1): 53-69. DOI:10.17759/exppsy.2019120105

Burkova, V.N., M.L. Butovskaya, D.A. Dronova, and J.I. Apal'kova. 2019. Empatija, trevozhnost' i agressija u moskovskih studentov [Empathy, Anxiety, and Aggression among Moscow Students]. Etnograficheskoe obozrenie 5: 169-188.

Cava, M.A., K.E. Fay, H.J. Beanlands, E.A. McCay, and R. Wignall. 2005. Risk perception and compliance with quarantine during the SARS outbreak. $J$ Nurs Scholarsh 37: 343-347. DOI: $10.1111 / \mathrm{j} .1547-5069.2005 .00059 . x$

Chirkov, V.I., R.M. Ryan, Y. Kim, and U. Kaplan. 2003. Differentiating autonomy from individualism and independence: A self-determination theory perspective on internalization of cultural orientations and well-being. Journal of Personality and Social Psychology 8(1): 97-110.

Fedenok, J.N., and V.N. Burkova. 2020. Social'noe distancirovanie kak al'truizm v uslovijah pandemii koronavirusa: kross-kul'turnoe issledovanie [Social distancing as altruism in the context of the coronavirus pandemic: a cross-cultural study]. Sibirskie istoricheskie issledovanija 2: 6-40.

Fenichel, E.P. 2013. Economic considerations for social distancing and behavioral based policies during an epidemic. Journal of Health Economics 32: 440-451. DOI: 10.1016/j. jhealeco.2013.01.002

Hofstede, G. 1981. Culture and organizations. International Studies of Management and Organizations 10: 15-41.

Hofstede, G. 2014. Model' Hofstede v kontekste: parametry kolichestvennoj harakteristiki kul'tur [Model' Hofstede in context: parameters of quantity characteristics of cultures]. Jazyk, kommunikacija i social'naja sreda 12: 9-49.

Hofstede, G. and R. McCrae. 2004. Personality and culture revisited: Linking traits and dimensions of culture. Cross-Cultural Research 38 (1): 52-88.

Hofstede, G., Hofstede, G.J., and Minkov, M. 2010. Cultures and Organizations: Software of the Mind. Revised and expanded third edition. New-York: McGraw-Hill.

House, R. J., P.J. Hanges, M. Javidan, P.W. Dorfman, and V. Gupta. (Eds.). 2004. Culture, leadership, and organizations: The GLOBE study of 62 societies. Sage publications.

Javidan, M. and A. Dastmalchian. 2009. Managerial implications of the GLOBE project: A study of 62 societies. Asia Pacific Journal of Human Resources 47(1): 41-58.

Kim, N. Ulichnye testy i SMS-rassylki: kak Juzhnaja Koreja vzjala pod kontrol' jepidemiju koronavirusa [Street tests and SMS: how South Korea has taken control of the coronavirus epidemic]. Forbes=Forbes. https://www.forbes.ru/tehnologii/395939-ulichnye-testy-i-smsrassylki-kak-yuzhnaya-koreya-vzyala-pod-kontrol-epidemiyu (Accessed 25.03.2020).

Lebedeva, N.M., V.I. Chirkov, and A.N. Tatarko. 2007. Kul'tura i otnoshenie k zdorov'ju: Rossija, Kanada, Kitaj [Culture and attitude to health: Russia, Canada, China]. Moscow.

Lo, J.Y.C., T.H.F. Tsang, Y.-H. Leung, E.Y.H. Yeung, T. Wu, and W.W.L. Lim. 2005. Respiratory infections during SARS outbreak, Hong Kong, 2003. Emerg Infect Dis 11: 1738-41. DOI: $10.3201 /$ eid1111.050729 
MacIntyre, C., S. Cauchemez, D.E. Dwyer, H. Seale, P. Cheung, and G. Browne. 2009. Face Mask Use and Control of Respiratory Virus Transmission in Households. Emerg Infect Dis 15 (2): 233-241. DOI: 10.3201/eid1502.081167

Ross, L., and Nisbett, R. 1999. Chelovek i situacija. Uroki social'noj psihologii [Person and situation: lessons of social psychology]. Moscow: Aspekt Press.

Syed, Q., W. Sopwith, M. Regan, and M.A. Bellis. 2003. Behind the mask. Journey through an epidemic: some observations of contrasting public health responses to SARS. J Epi Comm Health 57: 855-856.

Triandis, H.C. 1994. Culture and Social Behavior. New York: McGraw-Hill.

Van Kemenade, S. 2003. Social capital as a health determinant: how is it defined? Ottawa: Minister of Public Works and Government Services Canada. Working Paper 02-07. http://publications. gc.ca/collections/Collection/H13-5-02-7E.pdf

Vojtenko, V.P., V.A. Sokolov, and R.A. Lubskij. 2019. Kollektivizm i individualizm v Rossii kak predmet teoreticheskoj refleksii [Collectivism and individualism in Russia as a subject of theoretical reflection]. Filosofija prava 3(90): 71-77.

Zahn-Waxler, C., J.L. Robinson, and R.N. Emde. 1992. The Development of Empathy in Twins. Developmental Psychology 28(6): 1038-1047. DOI:10.1037/0012-1649.28.6.1038.

Burkova, Valentina N., Fedenok, Julia N.

\section{Medical mask as a means of personal and collective protection in the context of the COVID-19 pandemic (cross-cultural aspects)}

Using a medical mask is one of the ways to prevent the spread of respiratory infections, including COVID-19. The willingness to use the mask in different countries depends on a number of factors - epidemiological experience, cultural norms and attitudes, economic and political conditions, public awareness, etc. The purpose of this study is to analyze the first reaction of the population to prescriptions or recommendations of authorities to use medical masks as a means of personal protection during COVID-19 in different countries. We used methods of semi-structured in-depth interviews, questionnaires, photo-fixation of elements of people's behavior during the pandemic, content analysis of the media. In total, 366 questionnaires were collected (51 males and 315 females) among Russian-speaking people who were living or staying abroad at the time of the outbreak and spreading of COVID-19, as well as among Russians from different regions of Russia since March 23 to April 10, 2020. An analysis of the data showed that the willingness to use a mask depends on the country of residence of the respondent, gender, social distance and trust in the authorities. The results of the study demonstrate the effect of official decisions on the real behavior of people - the more serious are measures on the part of the government, the more responsible are people about preventive measures and the better they implement them. The results were interpreted from the point of view of "Individualism-Collectivism" dichotomous classification of cultures. These results are the first step of the study and reveal the first stage of people's response to the restrictions. Understanding of socio-cultural and ethnic circumstances of population's perception and implementation of sanitary-hygienic prescriptions can be used in choosing the most optimal ways of warning and developing efficient methods to encourage the population to adhere to restrictions.

Keywords: medical mask, coronavirus, COVID-19, sociocultural norms, individualism, collectivism, cross-cultural differences 